\title{
Evaluation of the Application of Online Learning in Indonesian Universities
}

\author{
Rudi Setiawan ${ }^{1}$, Robiatul Munajah ${ }^{2}$ \\ ${ }^{1}$ Information System Departement, Trilogi University, South Jakarta, Indonesia \\ ${ }^{2}$ Primary School Departement, Trilogi University, South Jakarta, Indonesia
}

\begin{abstract}
The Ministry of Education and Culture of the Republic of Indonesia has issued a quality assurance manual for online learning processes that can be used by all universities in Indonesia to evaluate the results of implementing online learning lectures that have been implemented in each college. There are 4 assessment categories in this research. Average interpretation value of the evaluation of the application of learning at Trilogi University had a percentage of $\mathbf{7 5 . 6 9 \%}$ which indicated that it had gone well, but it was necessary to improve the learning assistance service instrument because the results of the study showed percentage of $69.87 \%$.
\end{abstract}

Keywords - online learning, education, online education, Indonesian online learning, Indonesian education.

\section{Introduction}

The era of industrial revolution 4.0 technology plays an important role in human life [1]. It happens because technology offers convenience in helping to solve every human work [2], not least in the world of education. With technology now, teaching and learning activities become unlimited by time and space [3]. According to [4], the use of technology in the classroom has the benefit of increasing academic achievement from the perspective of students and educators.

DOI: $10.18421 /$ TEM93-46

https://doi.org/10.18421/TEM93-46

Corresponding author: Rudi Setiawan,

Information System Departement, Trilogi University,

South Jakarta, Indonesia.

Email: rudi@trilogi.ac.id

Received: 18 March 2020.

Revised: 11 June 2020.

Accepted: 18 June 2020.

Published: 28 August 2020.

(cc) BY-NC-ND (C) 2020 Rudi Setiawan \& Robiatul Munajah; published by UIKTEN. This work is licensed under the Creative Commons Attribution-NonCommercial-NoDerivs 4.0 License.

The article is published with Open Access at www.temjournal.com
And by learning the current generation through the help of technology, now they can access a lot of information in just one click [5].

Of course, this changes the paradigm in learning where the teaching and learning process in education has been replaced by technology [6]. Education must continue to evolve to meet the challenges of a rapidly changing and unpredictable world [7]. Currently learning using e-learning in Indonesia is starting to be used in line with the Ministry of Education's idea of an independent campus and freedom of learning.

To be able to implement learning with the help of technology, good preparation before implementation is an important role for the smooth learning process [8], [9]. The facts in the field show that each institution has a different level of readiness [10]. One implementation strategy for e-learning development is the availability of e-learning infrastructure [11] and according to [12], the challenges when implementing e-learning are divided into three categories namely technology, content and people. Other factors of successful implementation of elearning are institutional support and the provision of adequate interaction and feedback [13]. Corporate culture and leadership factors also influence the success of the application of e-learning [14].

The discussion on e-learning is inseparable from the discussion of the learning process which is an interaction that occurs between students, students with learning resources, and students and lecturers who provide effective learning experiences towards learning outcomes. In general, the purpose of the learning evaluation is to find out the effectiveness and efficiency of the learning system broadly [15]. So that learning outcomes can be met, it is necessary to evaluate the learning activities that have been carried out. The Ministry of Education and Culture of the Republic of Indonesia through the directorate general of Higher Education has issued a quality assurance manual for online learning that can be used by all universities in Indonesia to evaluate the results of implementing online learning lectures that have been applied in each of the tertiary institutions. In this study, the evaluation of the results of online learning lectures was conducted using an assessment instrument provided by the Ministry of Education and Culture of the Republic of Indonesia in 2014. 


\section{Methods}

The assessment instrument was taken from the online learning process quality assurance book issued by the Directorate of Learning and Student Affairs of the Ministry of Education and Culture [16]. The research data was taken in the odd semester of the 2019-2020 at the Trilogi University in South Jakarta. It was based on the results of filling out the questionnaire conducted by students enrolled in the eLearning lecture with 132 respondents. This research is a quantitative descriptive study, filling in the data is done with the help of Google form consisting of 4 assessment instruments with a Likert scale answer form. The conversion table of interval values from the calculation of interpretation values is shown in Table 1.

Table 1. Conversion interpretation value

\begin{tabular}{ll}
\hline Interval & Description \\
\hline $0-24.99 \%$ & Less Good \\
$25-49.99 \%$ & Fair \\
$50 \%-74.99 \%$ & Good \\
$75 \%-100 \%$ & Very Good \\
\hline
\end{tabular}

Analysis of the results of the assessment instrument is done by calculating the value of interpretation $(\mathrm{Pi})$ of each answer by first calculating the highest score Likert multiplied by the number of respondents and calculate the total score respondent assessment. More about calculating the percentage of interpretive values are presented in the following formula:

$$
\mathrm{Pi}=\text { Total Score } / \mathrm{Y} * 100 \quad \begin{gathered}
\ldots . \text { Calculation of } \\
\text { interpretation value }
\end{gathered}
$$

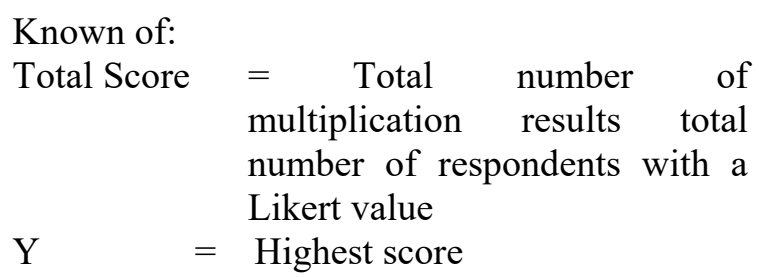

\section{Results and Discussion}

\subsection{Questionnaire Result}

Evaluation is used to answer various questions about the program being evaluated [17]. Questions on the assessment instrument were taken from the online learning process quality assurance manual issued by the Directorate of Learning and Student Affairs of the Ministry of Education and Culture [16] so that the assessment instrument questions were considered valid so that no validity and reliability tests were conducted on the instrument question. The research subjects were conducted for students who had carried out lectures with blended learning in the 2019-2020 school year odd semester.
Table 2. shows the results of obtaining questionnaires in the online learning activities assessment instrument carried out by respondents.

In questions with the instrument code IPKPD.1, the largest number of respondents was selected in point number 3 which means there are instructions on how to study the material that explains the freedom of students to learn with total respondents 57 students. The question with the instrument code IPKPD.2, the highest number of respondents was chosen in point number 3 which means the presentation of the lecture material seeks to upload

Table 2. Results of Questionnaire evaluation on Online

\begin{tabular}{|c|c|c|c|c|c|}
\hline 泀 & $\begin{array}{l}\text { Online Learning } \\
\text { Activity } \\
\text { Assessment } \\
\text { Instrument }\end{array}$ & 1 & 2 & 3 & 4 \\
\hline 㐫 & $\begin{array}{l}\text { Availability of } \\
\text { instructions on } \\
\text { how to study the } \\
\text { material }\end{array}$ & 12 & 40 & 57 & 23 \\
\hline$\overbrace{\hat{\theta}}^{2}$ & $\begin{array}{l}\text { Presentation can } \\
\text { arouse the desire } \\
\text { of students to learn } \\
\text { through } \\
\text { illustrations in the } \\
\text { form of multi } \\
\text { media }\end{array}$ & & 23 & 78 & 31 \\
\hline 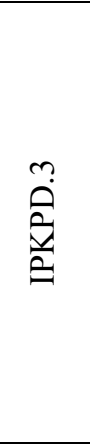 & $\begin{array}{l}\text { Facilitating the } \\
\text { diversity of } \\
\text { learning } \\
\text { interactions } \\
\text { (students with } \\
\text { material, students } \\
\text { with students, } \\
\text { students with } \\
\text { lecturers / tutors) } \\
\text { synchronously and } \\
\text { asynchronously }\end{array}$ & & 31 & 64 & 37 \\
\hline$\stackrel{+}{\stackrel{v}{a}}$ & $\begin{array}{l}\text { Presentation } \\
\text { allows students to } \\
\text { learn iteratively } \\
\text { (repeatedly) } \\
\text { independently. }\end{array}$ & & & 20 & 112 \\
\hline$\frac{n}{2}$ & $\begin{array}{l}\text { Presentation of } \\
\text { feedback that } \\
\text { allows students to } \\
\text { know their } \\
\text { learning } \\
\text { achievements }\end{array}$ & & 29 & 84 & 19 \\
\hline
\end{tabular}
Learning Activities Instrument

the desire of students to study with the number of respondents who chose 78 students. Regarding questions with the instrument code IPKPD.3, the highest point is in answer choice number 3 which means that there is a minimum interaction facility provided with lecturers with 64 respondents. The question on the instrument code is IPKPD.4, the 
highest score is answer choice number 4 which means the presentation of the material allows students to study repeatedly independently with the number of respondents choosing 112 students. The last question from the assessment of the IPKPD instrument.5, the highest point is in answer choice number 3 which means that feedback is given only by lecturers with total respondents 84 students.

Table 3. shows the results of filling out the questionnaire on the online learning strategy assessment instrument conducted by respondents.

Table 3. Results of Questionnaire evaluation on Online Learning Strategy Instrument

\begin{tabular}{|c|c|c|c|c|c|}
\hline 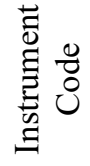 & $\begin{array}{l}\text { Online Learning Strategy } \\
\text { Instrument }\end{array}$ & 1 & 2 & 3 & 4 \\
\hline $\overrightarrow{\tilde{a}}$ & $\begin{array}{l}\text { Facilitating a variety of } \\
\text { learning strategies } \\
\text { (independent learning, } \\
\text { group discussions, } \\
\text { guided learning) }\end{array}$ & & 37 & 72 & 23 \\
\hline ڤุ & $\begin{array}{l}\text { Encourage the growth of } \\
\text { new ideas (not single } \\
\text { answers) in the form of } \\
\text { critical questions, } \\
\text { illustrations, actual } \\
\text { issues, problems that } \\
\text { require continued } \\
\text { thinking / creative } \\
\text { solutions }\end{array}$ & & 28 & 69 & 35 \\
\hline$\stackrel{m}{\tilde{\omega}}$ & $\begin{array}{l}\text { Presentation of the } \\
\text { learning object } \\
\text { systematically using } \\
\text { specific pedagogical } \\
\text { approaches }\end{array}$ & & 14 & 108 & 10 \\
\hline$\stackrel{+}{\stackrel{+}{\Omega}}$ & $\begin{array}{l}\text { Strategies used to allow } \\
\text { students to practice and } \\
\text { master the necessary } \\
\text { skills }\end{array}$ & & 33 & 78 & 21 \\
\hline
\end{tabular}

In questions with ISPD instrument code.1, the highest number of respondents was selected in point number 3 which means learning was carried out with group learning strategies along with the number of respondents choosing 72 students. Questions with the instrument code ISPD.2, the highest number of respondents was chosen in point number 3 which means that the guide questions, initiations and case studies facilitated low order thinking and higherorder thinking with the number of respondents who chose as many as 69 students. Regarding the ISPD. 3 instrument code question, the highest point is in answer choice number 3 which means that the pedagogical foundation used is diverse, the presentation of learning objects is quite adequate with the number of respondents choosing 108 students. The question in the ISPD instrument code.4, the highest score is in answer choice number 3 , which means the delivery strategy allows students to learn and practice the skills they need with a variety of media with the number of respondents choosing 78 students.

Table 4. shows the results of the questionnaire filling results in the media assessment instrument and learning technology conducted by respondents.

\section{Table 4. Results of Questionnaire evaluation on Media} Instrument and Learning Technology

\begin{tabular}{|c|l|c|c|c|c|}
\hline $\begin{array}{c}\text { Instrument } \\
\text { Code }\end{array}$ & $\begin{array}{l}\text { Media Instruments } \\
\text { and Learning } \\
\text { Technology }\end{array}$ & 1 & 2 & 3 & 4 \\
\hline IMTP.1 & $\begin{array}{l}\text { The use of various } \\
\text { learning media } \\
\text { allows students to } \\
\text { more easily } \\
\text { understand learning } \\
\text { material. }\end{array}$ & 36 & 17 & 47 & 32 \\
\hline IMTP.2 & $\begin{array}{l}\text { The use of visual } \\
\text { media and other } \\
\text { media related to the } \\
\text { material presented }\end{array}$ & $\begin{array}{l}\text { Selection of } \\
\text { learning media in a } \\
\text { format that is easily } \\
\text { accessible }\end{array}$ & 11 & 72 & 49 \\
\hline IMTP.3 & 14 & 118 \\
\hline
\end{tabular}

On questions with IMTP instrument code.1, the highest number of respondents was selected in point number 3, which means the media learning does not vary but according to the characteristics of the material presented by the number of respondents who chose as many as 47 students. Questions with the IMTP code 2, the largest number of respondents are in point number 3 , which means that the learning media is less clear in its integration with the material presented but is still relevant, with the number of respondents choosing 72 students. The last question with the IMTP instrument code. 3 , the highest point is in answer choice number 4 which means the learning media format used is easily accessible and of good quality with the number of respondents who chose 118 students.

Table 5. shows the results of filling out the questionnaire on the learning assistance service instrument conducted by respondents, in the ILBB instrument code. 1 , the highest number of respondents was selected in point number 4 which means academic and administrative information available online and always updated with the number of respondents choosing 130 students. Questions with the ILBB.2 instrument code, the highest number of respondents were in point number 2, which means that independent study guidance and learning strategies and learning styles were provided only in the form of pointers with the number of respondents who chose 65 students. Questions with the ILBB.3 
instrument code, the highest point is in answer choice number 3 which means that access to a variety of digital learning resources is provided only in the library of online subjects with 77 respondents choosing students. The last question with the instrument code ILBB.4, the highest point is in answer choice number 2 which means that technical assistance and complaints are provided only by telephone during working hours with the number of respondents choosing 93 students.

Table 5. Results of Questionnaire evaluation on Learning Aid Service Instrument

\begin{tabular}{|c|c|c|c|c|c|}
\hline 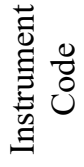 & $\begin{array}{l}\text { Learning Aid Service } \\
\text { Instrument }\end{array}$ & 1 & 2 & 3 & 4 \\
\hline$\vec{m}$ & $\begin{array}{l}\text { Availability of } \\
\text { academic and } \\
\text { administrative } \\
\text { information services }\end{array}$ & & & 2 & 130 \\
\hline$\stackrel{\sim}{m}$ & $\begin{array}{l}\text { Availability of distance } \\
\text { learning tutoring and } \\
\text { independent }\end{array}$ & 23 & 65 & 29 & 6 \\
\hline$\stackrel{m}{m}$ & $\begin{array}{l}\text { Availability of access to } \\
\text { digital learning } \\
\text { resources in the library }\end{array}$ & & 28 & 77 & 27 \\
\hline $\begin{array}{l}\dot{\nabla} \\
\stackrel{\oplus}{\oplus}\end{array}$ & $\begin{array}{l}\text { Availability of } \\
\text { technical assistance and } \\
\text { complaints }\end{array}$ & 6 & 93 & 33 & \\
\hline
\end{tabular}

\subsection{Discussion}

From the research data on the assessment of online learning activity instruments, the highest interpretation value is IPKPD. 4 with an interpretation value of $96.2 \%$ of respondents agree that in terms of presenting the material allows students learn to repeat independently. Whereas the lowest instrument and needs to be improved is in the instrument code of IPKPD.1 which is about the availability of instructions on how to study material with an interpretation value of $67.2 \%$. While the average value of interpretation in the assessment of online learning activity instruments was $77.82 \%$. More about the results of the calculation of the value of the interpretation of online learning activities are shown in Figure 1.

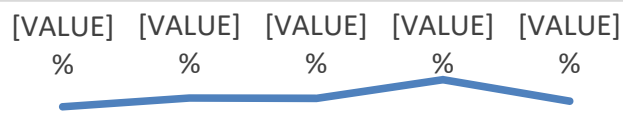

$\begin{array}{lllll}\text { IPKPD.1 } & \text { IPKPD.2 } & \text { IPKPD.3 } & \text { IPKPD.4 } & \text { IPKPD.5 }\end{array}$

Figure 1. Results of Calculation of Interpretation Value of Online Learning Activities
From the research data on the assessment of online learning strategy instruments, the highest interpretation value is at ISPD.2 with an interpretation value of $76.3 \%$ of respondents agreed that guide questions, initiations and case studies facilitate both low-order thinking and higher-order thinking. Whereas the lowest instrument and needs to be improved is in the ISPD instrument code. 1 namely regarding learning implemented with group learning strategies alone with an interpretation value of $72.3 \%$. While the average value of interpretation in the assessment of online learning strategy instruments was $73.87 \%$. More about the results of the calculation of the value of the interpretation of online learning strategies are shown in Figure 2.

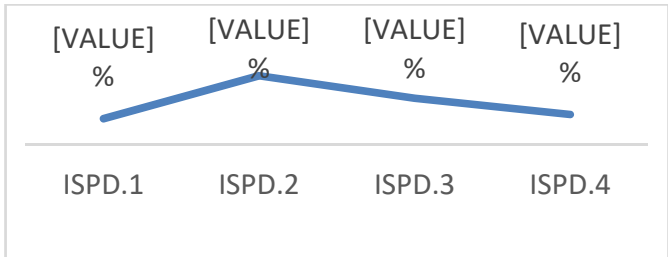

Figure 2. Results of Calculation of Interpretation Value of Online Learning Strategies

From the research data on the assessment of media instruments and learning technology, the highest interpretation value is at IMTP.3 with an interpretation value of $97.3 \%$ of respondents agreed that the learning media format used was easily accessible and of good quality. Whereas the lowest instrument and needs to be improved is in the IMTP instrument code.1, namely the learning media does not vary but according to the characteristics of the material presented with an interpretation value of $64.2 \%$. While the average value of interpretation of the assessment of media instruments and learning technology is $81.23 \%$. More about the results of the calculation of the interpretation of the media and instructional technology is shown in Figure 3.

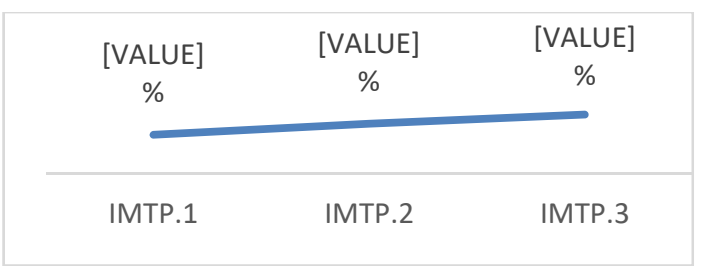

Figure 3. Calculation Result Interpretation Values Against Media and Technology Learning

From the research data on the assessment instrument learning support services, the value of the highest interpretation is at ILBB.1 value interpretation $99.6 \%$ of respondents agreed that academic and administrative information is available online and is always updated. Whereas the lowest instrument and needs to be improved is in the ILBB instrument code.2, namely regarding the availability 
of distance and independent learning guidance only provided independent study guide and learning strategies and learning styles only in the form of pointers with $50 \%$ interpretation value. While the average value of interpretation of the assessment of instruments is learning assistance service $69.87 \%$. More about the results of the calculation of the interpretation value of learning assistance services is shown in Figure 4.

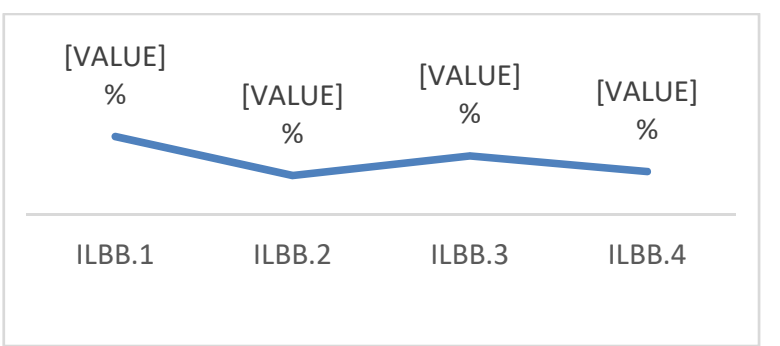

Figure 4. Results of Calculation of Interpretation Value of Learning Assistance Services

From the four assessment instruments, the average interpretation value of each instrument is shown in Table 5.

Table 5. Average interpretation value of each assessment instrument

\begin{tabular}{|c|c|c|c|}
\hline 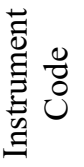 & Rating & $\begin{array}{c}\text { Average } \\
\text { interpretation } \\
\text { value }\end{array}$ & Description \\
\hline$\frac{\hat{\theta}}{\hat{\theta}}$ & $\begin{array}{c}\text { Online Learning } \\
\text { Activities }\end{array}$ & $77.82 \%$ & Very Good \\
\hline$\hat{\tilde{\Omega}}$ & $\begin{array}{l}\text { Online Learning } \\
\text { Strategies }\end{array}$ & $73.87 \%$ & Good \\
\hline$\sum_{\text {E }}$ & $\begin{array}{l}\text { Media and } \\
\text { Learning } \\
\text { Technology }\end{array}$ & $81.23 \%$ & Very Good \\
\hline$\stackrel{\oplus}{\oplus}$ & $\begin{array}{l}\text { Learning } \\
\text { Assistance } \\
\text { Services }\end{array}$ & $69.87 \%$ & Good \\
\hline \multicolumn{2}{|c|}{$\begin{array}{l}\text { Average Interpretation } \\
\text { value }\end{array}$} & $75.69 \%$ & Very Good \\
\hline
\end{tabular}

\section{Conclusion}

Based on the results of the discussion, the total average interpretation value from the evaluation of the application of learning at Trilogi University has a percentage of $75.69 \%$, which indicates the implementation of e-learning at Trilogi University has been going very well, although the results show that it is necessary to improve the learning assistance service instrument because the results of the study show the lowest percentage of interpretation is in learning assistance services with a percentage of $69.87 \%$.

Suggestions for researchers and learning managers in universities especially in Indonesia, in addition to using assessment instruments that have been provided by the government, other assessment instruments that are sourced from the results of previous studies should also be included to obtain more comprehensive evaluation results.

\section{References}

[1]. Raja, R., \& Nagasubramani, P. C. (2018). Impact of modern technology in education. Journal of Applied and Advanced Research, 3(S1), 33-35.

[2]. Daghan, G. (2017). Views of Students about Technology, Effects of Technology on Daily Living and Their Professional Preferences. Turkish Online Journal of Educational Technology-TOJET, 16(4), 187-194.

[3]. Andriani, T. (2015). Learning System Based on Information and Communication Technology. Journal of Social Culture: Communication Media, Social Sciences and Culture, 12(1), 127-150.

[4]. Marshall, S. (2011). Change, Technology and Higher Education: Are Universities Capable of Organisational Change?. Journal of Asynchronous Learning Networks, 15(4), 22-34. doi: 10.24059/olj.v15i4.203

[5]. Francis, J. (2017). The effects of technology on student motivation and engagement in classroombased learning. All Theses and Dissertations. 121. Retrieved from: httpp://dune.une.edu/theses/121 [accessed: 15 January 2020].

[6]. Bhakta, K., \& Dutta, N. (2016). Impact of information technology on teaching-learning process. International Research Journal of Interdisciplinary \& Multidisciplinary Studies, 2(11), 131-138.

[7]. Serdyukov, P. (2017). Innovation in education: what works, what doesn't, and what to do about it?. Journal of Research in Innovative Teaching \& Learning, 10(1), 4-33.

DOI: https://doi.org/10.1108/JRIT-10-2016-0007

[8]. Mutia, I., \& Leonard. (2013). Study on the Application of E-learning in the Learning Process in Higher Education. Journal Faktor Exacta 6(4), 278289.

[9]. Coopasami, M., Knight, S., \&' Pete, M. (2017). eLearning readiness amongst nursing students at the Durban University of Technology. health sa gesondheid, 22(1), 300-306.

[10].Vilkonis, R., Bakanovienè, T., \& Turskienè, S. (2013). Readiness of Adults to Learn Using Elearning, M-learning and T-learning Technologies. Informatics in Education, 12, 181-190.

[11]. Winarno., \& Setiawan, J. (2013). Implementation of the E-Learning System in the home school education community. Journal Ultima InfoSys, 4(1), 45-51. 
[12]. Dutta, A. K., Mosley, A. A., \& Akhtar, M. M. (2011). E-learning in higher education: Design and implementation. International Journal of Computer Science Issues (IJCSI), 8(4), 509-516.

[13]. Hew, K. F., \& Cheung, W. S. (2013). Designing and implementing e-learning courses: A comparative analysis of policy guidelines from nine professional organizations. International Journal of e-Education, e-Business, e-Management and e-Learning, 3(3), 178.

[14]. Djamaris, A., Priyanto, A. B., \& Jie, F. (2012, June). Implementation of e-learning system readiness: Indonesia context. In 2012 IEEE International Conference on Management of Innovation \& Technology (ICMIT) (pp. 314-319). IEEE.
[15]. Asrul., Ananda, R., \& Rosnita, (2014). Learning Evaluation, Citapustaka Media, Bandung. ISBN. 978-602-1317-49-5

[16]. Quality assurance guidelines for online learning processes. (2014). The Directorate of Learning and Student Affairs, the Ministry of Education and Culture of the Republic of Indonesia.

[17]. Harjanti, R., Supriyati, Y., \& Rahayu, W. (2019). Evaluation of Learning Programs at Elementary School Level of "Sekolah Alam Indonesia (SAI)".(Evaluative Research Using Countenance Stake's Model). American Journal of Educational Research, 7(2), 125-132. doi: 10.12691/education-7-2-2. 